\author{
Review Article
}

\title{
VRIKSHAYURVED PLANTATION TECHNIQUES: A REVIEW
}

\begin{abstract}
Abnave Prajkta Dilip ${ }^{1 *}$, Avalaskar Amit D ${ }^{2}$
*1PG Scholar, ${ }^{2}$ Associate Professor, Department of Dravyaguna vigyan, Sumatibhai Shah Ayurved Mahavidyalaya, Pune, Maharashtra, India.
\end{abstract}

\begin{tabular}{|c|c|}
\hline Articl & \multirow{9}{*}{$\begin{array}{l}\text { ABSTRACT } \\
\text { Use of chemicals for plant growth and its management has led to soil and water pollution. It } \\
\text { has ultimately affected the quality of medicinal plants. In the other hand Vrikshayurved } \\
\text { (science of plant life) have fully organic and time tested methods to deal with entire plant } \\
\text { life. It mostly emphasizes on the selection of land, seed collection, seed treatment, different } \\
\text { plant propagation methods, irrigation, manure, plant protection, plant disease } \\
\text { management, crop harvesting and storage of produce. Thus, Vrikshayurved encompasses } \\
\text { both agriculture and forestry. } \\
\text { Materials and method- Collection and compilation of useful information has been done } \\
\text { from concerned articles and texts of Ayurved and Vrikshayurved texts such as Surpala's } \\
\text { Vrikshayurved, Upavan Vinod, Varahamihir's Brihat Samhita, Charak Samhita and Sushruta } \\
\text { Samhita. } \\
\text { Discussion and Conclusion- This article represents concise information of Vrikshayurved } \\
\text { plantation techniques for seed propagation, grafting, stem propagation, tuber propagation } \\
\text { and plant transplantation. All these methods are affordable, natural, and chemical free. All } \\
\text { substances used by Vrikshayurved methodology have its Ayurvedic significance. Thus, } \\
\text { Vrikshayurved and Manushya Ayurved are interdependent. Use of Vrikshayurved in modern } \\
\text { agriculture and forestry can result in better agriculture system and sustainable forestry. } \\
\text { Hence formation of standard guidelines for Vrikshayurved methodologies through research } \\
\text { work is mandatory for better tomorrow. }\end{array}$} \\
\hline & \\
\hline & \\
\hline & \\
\hline & \\
\hline & \\
\hline & \\
\hline & \\
\hline & \\
\hline
\end{tabular}

\section{INTRODUCTION}

Ayurved is the science of life which means it deals with life of every living substance that is animals \& plants. Conventionally Ayurved is concerned with human life. The Ayurveda is divided into three branches Manushya Ayurved for treating humans, Pashu Ayurved for treatment of animals and Vrikshayurved for management of plant life. Plants science (Vrikshayurved) has given equal and important weightage just like human science and animal science in Vedas.

\begin{tabular}{|l|l|}
\hline \multicolumn{3}{|c|}{ Access this article online } \\
\hline Quick Response Code & \begin{tabular}{l} 
https://doi.org/10.47070/ijapr.v9i8.2043 \\
\hline
\end{tabular} \\
\hline
\end{tabular}

Global focus on Ayurved has tremendously increased demand for raw plant materials worldwide, on other hand the increasing population and ongoing development in India is a cause of the rapid destruction of forests and agriculture lands. To fulfill the need of today's time, it is very important to focus on the forestry, agriculture system and plantation of medicinal plants.

Modern science focuses on the use of chemical compounds in agriculture which may result in increased final yield, but it also damages soil and water quality and can also damage the nutritional quality of the plants in a longer perception, in other hand Vrikshayurved methodology are natural, organic and causes nourishment of soil hence helps in Prashasta bhumi nirman (construction of good quality of soil).

\section{MATERIALS AND METHODS}

Materials: Surpala's Vrikshayurved, Upavan Vinod, Varahamihir's Brihat Samhita, Sushruta Samhita, Charak Samhita with their commentaries and other 
texts, published articles regarding Vrikshayurved and Ayurved.

Methods: Collection of various information of plantation from different texts and articles and compilation of the information related to Vrikshayurved plantation techniques.

Plants for different methods of plant propagation mentioned in Surpala's Vrikshayurved and Upavan Vinod[2,3]

\section{A. Seed- Propagated Plants}

\begin{tabular}{|l|l|l|}
\hline Jambu (Syzygium cumini L.) & Champaka (Magnolia champaca L.) & Punnaga (Calophyllum inophyllum L.) \\
\hline Nagakesara (Mesua ferrea L.) & Chimchika (Tamarindus indica L.) & $\begin{array}{l}\text { Kapittha (Feronia limonia (L.) } \\
\text { Swingle) }\end{array}$ \\
\hline Badara (Ziziphus mauritiana) & Bilva (Aegle marmelos L.) & Kumbhakari (Dolichos biflorus L) [7] \\
\hline $\begin{array}{l}\text { Priyangu (Callicarpa macrophylla } \\
\text { Viahl.) }\end{array}$ & $\begin{array}{l}\text { Panasa (Artocarpus heterophyllus } \\
\text { Lam) }\end{array}$ & Madhuka (Madhuca longifolia) \\
\hline Karamarda (Carissa carandas) & Amra (Mangifera indica) & \\
\hline
\end{tabular}

B. Kandaj (portion of stem-cutting method)

\begin{tabular}{|l|l|l}
\hline Tambula (Piper betle) & Sinduvara (Vitex Negundo Linn.) & Tagara Valeriana wallichii DC
\end{tabular}

C. Beeja kanda udbhava = Seeds and Stem Propagated Plants

\begin{tabular}{|l|l|l|}
\hline $\begin{array}{l}\text { Patala (Stereosprmum sauvealens } \\
\text { DC) }\end{array}$ & Dadima (Punica granatam Linn) & Plaksa (Ficus lacor Buch) \\
\hline Karavira (Nerium indicum) & Vata Ficus benghalensis Linn & Mallika (Jasminum sambac) \\
\hline Udumbara (Ficus racemosa. L.) & Kunda Jasminum multiflorum & \\
\hline
\end{tabular}

D. Kanda $=$ Tuber-bulb Propagated Plants

\begin{tabular}{|l|l|l}
\hline Kumkuma (Crocus sativus) & Kakubha Terminalia arjuna (Roxb) & Ardra (ardraka) Zingiber officinale \\
\hline Aluka (Dioscorea species) & Rason (allium sativum L.) & \\
\hline
\end{tabular}

E. Seed- Tuber Propagated Plants

\begin{tabular}{|l|l|l}
\hline $\begin{array}{l}\text { Ela (Elettaria cardamomum } \\
\text { Maton) }\end{array}$ & Padma (Nelumbo nucifera) & Utpala (Nymphaea alba Linn)
\end{tabular}

\section{Plant Propagation by Seeds}

Kautilya considered seed as the most important component of agriculture and therefore gave much emphasis on the procurement of quality seeds, their preservation, production, and distribution. ${ }^{[4]}$

\section{Seed selection criteria of Vrikshayurved $[5,6]$}

1. Seeds from well matured fruits

2. Seeds from fruits grown in fruiting season.

Common Seed treatment by Upavan Vinod and Surpala's Vrikshayurved ${ }^{[8,9]}$

1. Ripened and matured fruits are collected and dried then seeds are removed from fruits. Godugdha (cow milk) is sprinkled (Nishikta) on seeds and dried again. Same procedure is repeated for next 5 days- (Panchdinani). Then seeds are fumigated (Dhupitam) by Go-ghruta (cow ghee) \& Vidanga churna.

2. Seeds should be treated by sprinkling milk, then the seeds should be pasted (Liptam) with the paste (Kalka) of Brihati (Solanum indicum L.), Tila
(Sesamum indicum L.), Bhasma (of cow dung ash) and Sarshapa (Brassica nigra Koch.). Subsequently, the seeds should be rubbed (Mardita) with Gomaya (cow-dung) and clay soil (Mrida). Further, seeds material should be fumigated with fat.

3. The seeds should be sprinkled/dipped (Nishikta) in milk and then Gomaya should be rubbed/ pasted (Purimardita) on it. Then this seed material should be rubbed thoroughly (Bahusho mruditam) with Madhu (honey) and Vidanga Churna.

A. Seed treatment by Surpala's Vrikshayurved [10]

1. Seeds should be soaked in milk (Kshiren bhavitam) and allowed for drying up. Then fine powder consisting of Sarshap, Brihati, Tila, Nala (Kamal danda) should be dusted.

Surpala's Vrikshayurved mentions that Makanda (Mangifera indica L.), Jambu and Panasa seeds are better germinated by the above processes. 
2. Seed treatment of Rajadan (Mimusops hexandra Roxb.) and Bakul (Mimusops elengi L.) - the seeds of Rajadan and Bakul, after above common procedures, are further dried then their heads are cut. This process results in better viability.

3. Seed treatment of Ervaru (Cucumis melo L.)- The seeds of Ervaru are wrapped and tied with a platter (Patraputi) and jaggery solution (Guda dissolved in water) is sprayed (Sikta). Then they are heated up (Tapta) for three days and taken out. In this way, such seeds become viable with their better results of sowing and growth (Vapana yogya).

4. Seed sowing according to seed size and shapeSurpala's Vrikshayurved also emphasizes on different methods of sowing of seeds according to seed sizes.

Large size seed- sown singly

Small and minute seeds- spread by dispersal (Vikisna), in multiple or numerous quantities.

The shape of seeds is also considered for sowing. Naranga (Citrus reticulata Blanco) seeds are curved (tiryak) so should be sown in the same (standing) position.[11]

\section{B. Seed treatment by Varahamihir's- Brihat Samhita[12]}

1. General practice of sowing seeds- It involves soaking them in Dugdha (milk) for ten days, taking out daily with hand, smearing with ghee, rolling many times in cow dung, and fumigating with the flesh of deer or hog. Then the seeds were sown in a soil which was already treated with sesamum crushed together with flesh and hog's marrow.

2. Instant sprouting and fruiting - soak the seeds hundred times in a fruit paste of Ankola (Alangium salvifolium L.) or Sleshmataka (Cordia dichotoma Forst.F) or in its oil and sow in a soil mixed with hail (frozen rainwater).

3. Hard cover seeds - Hard seeds like tamarind are better sprouted when they are sprinkled with a mixture of the flour of rice, black gram and Tila and wheat particles along with stale meat and fumigated it repeatedly with turmeric powder.

4. Sleshmantaka - For Sleshmantaka, the shell of the seeds should be removed, then soaked in water, mixed with the paste of Ankola fruits and dried in the shade seven times, rubbed with buffalo dung and stored in the dry dung. The seeds were then sown in a soil soaked with hail water.

\section{Stem (cuttings) Propagation - Kanda pratiropana[13]}

Surpala's Vrikshayurved by mentions stem propagation techniques as follow-

1. Selection criteria of stem for propagation - Kanda or Vrunta (stem or twig/cutting) of a plant to be propagated should be 18 angula long, neither it should be very soft (tender) nor very hard.

2. Stem propagation methods -

- The stem should be pasted half with an adequate quantity of Gomaya (cow dung). This (stem cutting) should be planted (Sanropana) in the pit by inserting underground up to $3 / 4$ part (Tribhaga). Then, the irrigation (Sinchana) by water mixed with fine sand and clay (Mruttika) should be done.

- Any stem or branch (twig) should be pasted with ripe fruit-pulp of naturally matured Kadali (banana) then kept under sunlight till it gets fully dry. The rope, (cord) made of Shashti rice (rice variety that matures in sixty days), is tied on that. Then the same stem or twig should be planted in the pit. Subsequently it should be followed by droplet irrigation or irrigation with a little bit of water gradually (Stoka jala parisikta) during the summer season.

- Stem cutting for Shatapatrika (Rosa centifolia) plant - The lower part (Adhobhaga) of stem or branch (twig) should be semi-matured (Ardhapaka). It should be propagated during month Kartika (time after rains/ post- monsoon season). After this, it should be irrigated constantly for two months (Daruplavayet salile), so that the propagated plant-material should remain almost submerged in water during this period.

- Cow dung (Gomaya) is considered as best material for Kanda ropana in plants whose branches get easily bent down (Anamya) like Karavira (Nerium indicum) and Dadima (Punica granatam Linn).

3. Irrigation - The irrigation of water (Salila) to the propagated stem twig should be continued for two months (Māsadvaya) regularly (Nityam).

4. Further transplantation of stem -

When propagated stem or twig bears leaves or covered with leaves (Pallavita) within the period of two months, the same should be taken out and transfer to the appropriate place (beds). Transplantation is favorably followed up during the month of Ashadha (beginning of rains), the Bhumi and Disha (lands and direction) need to be examined for their appropriates and accordingly.

\section{Grafting [14,15]}

Varahamihira's Brihat Samhita has recorded two methods of grafting. They are: (i) inserting the cutting of a plant into the root of another, cut off from its trunk, and (ii) inserting the cutting of a tree into the stem of another. The junction of the two in both the cases was covered with a coating of mud and Gomaya (cow dung).

Plants mentioned for grafting by Brihat samhita = Panasa, Ashoka (Saraca asoca (Roxb.) 
Willd.), Kadali, Jambu, Lakuch (Artocarpus lakoocha Rox), Dadima, draksha (Vitis vinifera L.), Bijapurak (Citrus medica).

\section{Graft Plantation According to Seasons}

\begin{tabular}{|l|l|}
\hline Plant condition & Grafting Ritu (season) \\
\hline $\begin{array}{l}\text { Plants without } \\
\text { branch development }\end{array}$ & $\begin{array}{l}\text { Shishira (Mid- January to } \\
\text { Mid-March) }\end{array}$ \\
\hline $\begin{array}{l}\text { Plants with } \\
\text { developed branches }\end{array}$ & $\begin{array}{l}\text { Hemant (Mid-November } \\
\text { to Mid-January) }\end{array}$ \\
\hline $\begin{array}{l}\text { Plants with large, } \\
\text { developed branches }\end{array}$ & $\begin{array}{l}\text { Varsha (Mid-July to Mid- } \\
\text { September) }\end{array}$ \\
\hline
\end{tabular}

Irrigation $=$ The grafted trees were to be watered both in the morning and evening every day in summer, on alternate days in the cold season and whenever the soil becomes dry in the rainy season.

\section{Propagation of Tubers ${ }^{[16]}$}

Vrikshayurved by Surapal mentioned Ela, Padma and Utpala as suitable plant to be propagated by Kanda (tuber/ rhizome)

Pit preparation- Pit for (Sarva kanda) all tuber, rhizome propagation should be of 1 Hasta in length, breadth and depth in measurement and such pits to be filled with (Paripurita) with soil mixed with sand.

\section{Plant Transplantation Techniques}

1. Surpala's book of Vrikshayurved mentions plant transplantation method according to size of the plant, if the plant is a small herb or tiny seedlings (Balataru) then it should be propagated/ transplanted during daytime, in definite direction. When they attain growth to certain (desired) proportion, then their roots should be pasted with a recipe consisting of Madhu, lotus-stalk (Mrnāla), Ghrita and Vidanga (fruit/seeds powder). Finally, this plant-material should again be covered with soil and made underground in the pit. In case of the propagation for large plants (Mahantaru), the same procedure for transplantation (Pratyaropana) should be followed up except the timing is specifically evening for large plant.[17]

2. Plant transplantation by Upavan Vinod[18]

- Plant transplantation criteria - A sprouted plant when grows to about 1 cubit can be transplanted.

- Pit preparation - One should plant a tree (seedling) in a pit two cubits in depth, well-watered, filled with fine dusts of earth free from sands, and filled with Gomaya (cow dung).

\section{Transplantation Procedure}

- First sprinkle Godugdha to the plant then dig the plant few inches away from the stem, take out the plant carefully keeping the soil intact to the roots. Then apply paste of Ushira (Vetiveria zizanioides L.), Vidanga and Ghrita to the exposed roots. Then replant it in a pit together with cow dung.
- Plantain sprouts and Kshiri (with milky sap) trees should be planted after applying only Gomay to their roots.

\section{DISCUSSION}

- Sushrut Samhita, while describing fertilization in humans, mentioned seed germination process ${ }^{[19]}$. Good and matured seed (Beeja) germinates when proper Ritu (season), Kshetra (place), and Ambu (water), are available. Sushruta has not used term mruda. Sushruta might have pointed out that plants can be grown without soil. Modern science has developed different ways of growing plants without soil like hydroponics and aeroponics.

- Plant Reproduction methods- Vrikshayurved has covered both sexual and asexual methods of reproduction. The grafting technology of plantation is explained in detail by Brihat Samhita and Surapala's Vrikshayurved emphasize on cutting and seed sowing techniques.

- Vrikshayurved seed treatment methods

The verse $52-54$ by Surpala's Vrikshayurved and verse 51-53 of Varahamihir's Upavan vinod are similar, but the commentators have translated the Shlokas differently. Also, the methodology, use of materials and duration of procedure is not fully explored yet. Hence standardization of Vrikshayurved techniques is must.

- Plantation materials- Use of several materials for plantation are mentioned in ancient texts from time to time, all the texts give special emphasis on Gomaya (cow dung), Madhu (honey), Go-ghrita (clarified butter) and herbs like Vidang, Ushira, Kamal. All these materials are easily available, natural, and biodegradable.

- Gomay (cow dung) - Use of cow dung for dressing seeds, plastering cut ends of vegetative propagating units such as sugarcane setts, dressing wounds, sprinkling as a diluted suspension on plants and applying to soil has been indicated since the time of Kautilya (c.300 BC). When seeds are treated in various ways with cow dung, they get coated (pelleted) with cow dung residue. This residue contains cellulose, hemicelluloses, micronutrients, metabolic nitrogen, epithelial cells from the animal, bile salts and pigments, potash, sulphur, traces of phosphorus and a large number of bacteria, the majority of which are cellulose, hemicellulose and pectin fermenters. The cow dung residue has emulsifying properties. A thin dry layer of cow dung on a seed acts like blotting paper and readily absorbs moisture from the surrounding soil, which is to the advantage of the seed. The presence of bacteria in the residue may antagonize potential pathogens ready to attack the seeds.[20] 
Vidang-Vidanga is explained as Agrya (the best) Krimighna dravya. ${ }^{[21]}$ Embelia ribes berries contain several chemical constituents like embelin, volatile oil, fixed oil, resin, tannin, christembine (alkaloid), phenolic acids like caffeic acid, vanillic acid, chrorogenic acid, cinnamic acid, o-cumaric acid. $4.33 \%$ of the embelin content is observed in the berries of Embelia ribes. The major bioactive constituent of Vidanga is embelin, found to have antimicrobial activity.[22]

- Go-ghrita - Many uses of Ghrita are mentioned in different texts of Ayurveda. It is useful for maintenance of Jatharagni (digestive fire), pacifies Tridoshas and indicated for Rasayan karma and Snehan karma. Ghee contains 8\% lower saturated fatty acids which makes it easily digestible. Due to having 4-5\% linoleic acid, an essential fatty acid, it promotes proper growth of human and plant body. Ghee also contains vitamin A, B, E and K. Vitamin A and $E$ are antioxidant in nature and are helpful in preventing oxidative injury to the body.[23]

- Madhu-Sushruta Samhita has mentioned Madhu as Vranaropak.[24] proline peptide apidaecin present in honeybee saliva is antibacterial..25] Thus, it protects wounds in plants as it does in animals.

- Jivo jeevasya jeevanam (one living being is food for another living being)- Life of animals is totally dependent on plants. Plants provide nourishment, prevention and cure for the diseases in animals, in similar way animals provide nourishment, prevention and cure of diseases in plants. Use of animal body parts like bones, blood, flesh and excreta are well utilized in Vrikshayurved.

- Use of Tantra yukti

Indian ancient literature is written on the basis of Trantra yukti (tools for composing and understanding treatises). Application of Tantra yukti is necessary for understanding of Indian treatise then we can understand and gain precise knowledge from ancient Indian literature.

The Vrikshayurved texts mention different methods of plantations with some examples of plants. By using Tantra yukti and Yukti Praman, one can easily apply that knowledge to other plants.

- The plantation methodology Ardrak (Zingiber officinale Rose.) Ela (Elettaria cardamomum Maton) is described by Vrikshayurved. Both of them belong to Zingiberaceae family, as the family members possess similar structure and chemicals, we can apply the same knowledge for plantation of other family members from Zingiberaceae family.

Seed treatment for hard cover seeds is mentioned for tamarind seed. We can use the same treatment for other hard cover seeds, e.g., Fabaceae family plants, to reduce seed dormancy.

\section{CONCLUSION}

Vrikshayurved mentions many affordable, natural, and chemical free plantation solutions which are easy to implement in today's time. Utilization of Vrikshayurved knowledge in the field of agriculture and forestry is important. Vrikshayurved methodologies preserves quality of soil and water hence maintains environmental balance. Application of basic principles of Ayurved explained by Brihatrayi - Charak Samhita, Sushruta Samhita, and Ashtang sangraha should be implemented not only for Manushya Ayurved but also for Vrikshayurved and Pashu Ayurved. Formation of standard guidelines for Vrikshayurved methodologies through research work is the necessity of contemporary world.

\section{REFERENCES}

1. Majumdar G., Upavan Vinod, The Indian research institute, Calcutta, $1^{\text {st }}$ edition,1935, pg. 13

2. Pandey G., Vrikshayurved of Surpala, chowkhamba Sanskrit series office, Varanasi, $1^{\text {st }}$ edition 2010, section 6, verse 48-51, pg. 15,16

3. Majumdar G., Upavan Vinod, The Indian research institute, Calcutta, $1^{\text {st }}$ edition,1935, verse $46-49$ pp.72

4. Saxena R.C., Choudhary S.L., Nene Y.L.A textbook on Ancient History of Indian Agriculture, Asian Agri History Foundation, Secunderabad, 2009, chapter 8, pg. 50.

5. Pandey G., Vrikshayurved of Surpala, chowkhamba Sanskrit series office, Varanasi, $1^{\text {st }}$ edition 2010, section 7, verse 52, pg.18.

6. Majumdar G., Upavan Vinod, The Indian research institute, Calcutta, $1^{\text {st }}$ edition,1935, verse 51, pg. 73.

7. Shobhana MC, Kulkarni M. Kulatha: Therapeutic Approach-A Comprehensive Review. International Journal of Ayurveda and Pharma Research. 2017 May 2.

8. Pandey G., Vrikshayurved of Surpala, chowkhamba Sanskrit series office, Varanasi, $1^{\text {st }}$ edition 2010, section 7, verse 52-54, pg.18-20.

9. Majumdar G., Upavan Vinod, The Indian Research Institute, Calcutta, $1^{\text {st }}$ edition,1935, verse 51-53, pg. 73

10. Pandey G., Vrikshayurved of Surpala, chowkhamba Sanskrit series office, Varanasi, $1^{\text {st }}$ edition 2010, section 7, verse 55-57, pg.19-20.

11. Pandey G., Vrikshayurved of Surpala, chowkhamba Sanskrit series office, Varanasi, $1^{\text {st }}$ edition 2010, section 7, verse 72, pg.25.

12. Bhat M.R., Varahamihira'sbrhat Samhita, Jainendra Prakash Jain Industrial at Shri Jainendra Press, $1^{\text {st }}$ edition, reprint 1992, verse $19-21,27-30$ pg. 532535. 
13. Pandey G., Vrikshayurved of Surpala, Chowkhamba Sanskrit series office, Varanasi, $1^{\text {st }}$ edition 2010, section 8, verse 74-80, pg. 26-27.

14. Chandrashekharan $\quad$ B., Annadurai K., Somasundaram E., A textbook of Agronomy, New age International (P) Limited, Publishers, Hyderabad, 2010, 2.24, pg. 102.

15. Bhat M.R., Varahamihira's Brhat Samhita, Jainendra Prakash Jain Industrial At Shri Jainendra Press, $1^{\text {st }}$ edition, reprint 1992, verse 4-9, pg. 528-530.

16. Pandey G., Vrikshayurved of Surpala, Chowkhamba Sanskrit series office, Varanasi, $1^{\text {st }}$ edition 2010, section 8, verse 81, pg. 27.

17. Pandey G., Vrikshayurved of Surpala, Chowkhamba Sanskrit series office, Varanasi, $1^{\text {st }}$ edition 2010, section 8, verse 83-84, pg. 28.

18. Majumdar G., Upavan Vinod, The Indian Research Institute, Calcutta, $1^{\text {st }}$ edition, 1935 , verse $59-60$, pg. 73.

19. Sharma P.V., Sushruta Samhita, Chaukhamba surabharati prakashan, Varanasi, volume 2, Sharirsthan, chapter 2, verse 33. Pg. 21
20. Balasubramanian AV, Nirmala Devi TD. Traditional knowledge systems of India and Sri Lanka. In Compas Asian Regional Workshop on Traditional Knowledge Systems and their Current Relevance and Applications (2006: Bangalore, India) 2006. Centre for Indian Knowledge Systems. Pg. 36.

21. Tripathi R.V., Charak Samhita, Chaukhamba Sanskrit pratishthan, Sutrasthan, chapter 25, verse 40, pg. 338.

22. Lal, Mishra. Importance of Embelia Ribes: An Update International Journal of Pharmaceutical Sciences and Research 3823 IJPSR. 2013; 4(10): 3823-3838.

23. Singh M., Gaitonde H., Vaidya Anagha Chandan and Vaidya Rohit Mehta, Go Ghrita- Cow's Ghee - An Ayurvedic Approach, World Journal of Pharmacy And Pharmaceutical Sciences, Volume 8, Issue 9, pg. 1419.

24. Yadavji T., Sushruta Samhita, Chaukhamba Orientalia, Chikitsa sthan chapter 1, verse, pg.397.

25. Nene YL. Potential of some methods described in Vrikshayurvedas in crop yield increase and disease management. Asian Agri-History. 2012 Jan 1; 16(1): pg.35.

\section{Cite this article as:}

Abnave Prajkta Dilip, Avalaskar Amit D. Vrikshayurved Plantation Techniques: A Review. International Journal of Ayurveda and Pharma Research. 2021;9(8):34-39.

https://doi.org/10.47070/ijapr.v9i8.2043

Source of support: Nil, Conflict of interest: None Declared

\section{*Address for correspondence}

Dr. Abnave Prajkta Dilip

P.G. Scholar,

Department of Dravyaguna vigyan,

Sumatibhai Shah Ayurved

Mahavidyalaya, Pune,

Maharashtra, India.

Email: prajktaabnave@gmail.com

Disclaimer: IJAPR is solely owned by Mahadev Publications - dedicated to publish quality research, while every effort has been taken to verify the accuracy of the content published in our Journal. IJAPR cannot accept any responsibility or liability for the articles content which are published. The views expressed in articles by our contributing authors are not necessarily those of IJAPR editor or editorial board members. 